\title{
Sespendole, a New Inhibitor of Lipid Droplet Synthesis in Macrophages, Produced by Pseudobotrytis terrestris FKA-25
}

\author{
Ryuji Uchida, Yong-Pil Kim, Ichiji Namatame, Hiroshi Tomoda, Satoshi Ōmura
}

Received: September 26, 2005 / Accepted: January 26, 2006

(C) Japan Antibiotics Research Association

\begin{abstract}
Sespendole was isolated as an inhibitor of lipid droplet formation in macrophages from the culture broth of a fungal strain Pseudobotrytis terrestris FKA-25. The compound inhibited the synthesis of cholesteryl ester and triacylglycerol by mouse macrophages with $\mathrm{IC}_{50}$ values of 4.0 and $3.2 \mu \mathrm{M}$, respectively.
\end{abstract}

Keywords sespendole, lipid droplet synthesis, fungal metabolites, Pseudobotrytis terrestris, indolosesquiterpene

\section{Introduction}

Our research group has focused on discovery of biological active compounds from microbial metabolites [1 8]. Lipid droplet synthesis in macrophages is an early event in the process of macrophage foam cell formation, which leads to arteriosclerosis. During the course of screening for leads of anti-arteriosclerotic agents from microorganisms [9], a fungal strain FKA-25, identified as Pseudobotrytis terrestris [10,11], was found to produce an inhibitor of lipid droplet synthesis in macrophages. A novel compound designated sespendole with a unique diprenyl indolosesquiterpene skeleton (Fig. 1) was isolated from the culture broth. Previously indoloditerpene terpendoles [12 14] were discovered as inhibitors of acyl-CoA: cholesterol acyltransferase (ACAT) isolated from the culture broth of a fungus Albophoma [15]. The structure elucidation and biosynthesis of sespendole will be reported in the near future. In this paper, fermentation, isolation and biological properties of sespendole are described.

R. Uchida, H. Tomoda (Corresponding author): School of Pharmaceutical Sciences, Kitasato University, 5-9-1 Shirokane, Minato-ku, Tokyo 108-8641, Japan, E-mail: tomodah@pharm.kitasato-u.ac.jp

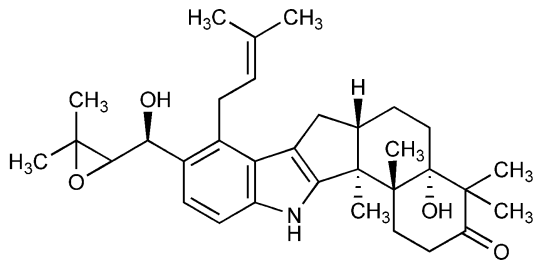

1

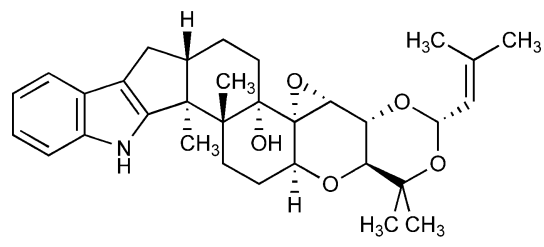

2

Fig. 1 Structures of sespendole (1) and terpendole C (2).

Furthermore, the inhibitory effects of sespendole and terpendole on lipid droplet formation in macrophages are compared.

\section{Materials and Methods}

\section{Fermentation Media}

For production of sespendole, the seed medium was used containing $2.0 \%$ glucose, $0.2 \%$ yeast extract (Oriental Yeast Co.), $0.05 \% \mathrm{MgSO}_{4} \cdot 7 \mathrm{H}_{2} \mathrm{O}, 0.5 \%$ Polypepton (Daigo Nutritive Chemicals), $0.1 \% \mathrm{KH}_{2} \mathrm{PO}_{4}$ and $0.1 \%$ agar. The $\mathrm{pH}$ was adjusted to 6.0 prior to sterilization. The production

Y. P. Kim, I. Namatame, S. Ōmura: Kitasato Institute for Life Sciences, Kitasato University and The Kitasato Institute, 5-9-1 Shirokane, Minato-ku, Tokyo 108-8641, Japan 
medium was composed of $2.0 \%$ sucrose, $1.0 \%$ glucose, $0.5 \%$ corn steep powder (Iwaki Co., Ltd.), $0.5 \%$ meat extract (Kyokuto Pharmaceutical Co. Ltd.), $0.1 \% \mathrm{KH}_{2} \mathrm{PO}_{4}$, $0.05 \% \mathrm{MgSO}_{4} \cdot 7 \mathrm{H}_{2} \mathrm{O}, 0.3 \% \mathrm{CaCO}_{3}$ and $0.1 \%$ agar. The $\mathrm{pH}$ was adjusted to 6.0 prior to sterilization.

\section{Quantitative Analysis of Sespendole by HPLC}

The amount of sespendole was measured by the analytical HPLC system (HP1100, Hewlett-Packard). Samples dissolved in methanol were analyzed under the following conditions: column, Symmetry C18/3.5 $\mu$ m (i.d. $2.1 \times 150$ $\mathrm{mm}$, Waters); mobile phase, a 20-minute linear gradient from $30 \% \mathrm{CH}_{3} \mathrm{CN} / 0.05 \% \mathrm{H}_{3} \mathrm{PO}_{4}$ to $70 \% \mathrm{CH}_{3} \mathrm{CN} / 0.05 \%$ $\mathrm{H}_{3} \mathrm{PO}_{4}$; flow rate, $0.2 \mathrm{ml} /$ minute; detection, $\mathrm{UV}$ at $240 \mathrm{~nm}$. Sespendole was eluted as a peak with a retention time of 17.8 minutes.

\section{Assay for $\left[{ }^{14} \mathrm{C}\right]$ Neutral Lipid Synthesis in Macrophages} Assay for $\left[{ }^{14} \mathrm{C}\right]$ cholesteryl ester $(\mathrm{CE})$ and $\left[{ }^{14} \mathrm{C}\right]$ triacylglycerol (TG) syntheses from $\left[{ }^{14} \mathrm{C}\right]$ oleic acid in macrophages was described previously [16]. In brief, mouse peritoneal macrophages $\left(5.0 \times 10^{5}\right.$ cells $/ 0.25 \mathrm{ml}$ GIT medium) were cultured in each well of a 48 -well plastic microplate (Corning Co.), and then a test sample $(2.5 \mu \mathrm{l}$ in $\mathrm{MeOH})$ and phosphatidylserine-containing liposomes $(10 \mu \mathrm{l})$ together with $\left[{ }^{14} \mathrm{C}\right]$ oleic acid $(0.05 \mu \mathrm{Ci}, 5 \mu \mathrm{l}$ in $10 \% \mathrm{EtOH} / \mathrm{PBS}$ solution) were added to each culture. Following a 14-hour incubation, the medium was removed, and the cells in each well were washed three times with PBS. The cells were lysed by adding $0.25 \mathrm{ml}$ of PBS containing $0.1 \%(\mathrm{w} / \mathrm{v})$ sodium dodecyl sulfate, and the cellular lipids were extracted by the method of Bligh and Dyer [17]. After removing the organic solvent, the total lipids were separated on a TLC plate (silica gel F254, $0.5 \mathrm{~mm}$ thick, Merck) using hexane - diethyl ether - acetic acid $(70: 30: 1)$ and were analyzed with a radioscanner (AMBIS Systems, Inc.).

\section{Assay for ACAT Activity}

ACAT activity in mouse liver microsomes was assayed by the method previously described [18] with some modifications. Briefly, an assay mixture containing $12.5 \mathrm{mg} / \mathrm{ml} \mathrm{BSA}$ in $104 \mathrm{mM}$ Tris- $\mathrm{HCl}(\mathrm{pH} 7.8)$ and $\left[{ }^{14} \mathrm{C}\right]$ oleoyl-CoA $(170 \mu \mathrm{M}, 0.1 \mu \mathrm{Ci})$ together with a test sample $(5.0 \mu \mathrm{l}$ in methanol to make a final concentration of $0 \sim 20 \mu \mathrm{M})$, and the microsomal fractions $(200 \mu \mathrm{g}$ of protein) prepared from mouse livers in a total volume of $100 \mu \mathrm{l}$ was incubated at $37^{\circ} \mathrm{C}$ for 15 minutes. The reaction was stopped by adding $0.5 \mathrm{ml}$ of ethanol, hexane $(1.5 \mathrm{ml})$ was then added, and the solutions were mixed well. The hexane layer $(1.0 \mathrm{ml})$ containing the product cholesteryl $\left[{ }^{14} \mathrm{C}\right]$ oleate was evaporated, and the residue was separated on a TLC plate using a petroleum ether - diethyl ether acetic acid $(90: 10: 1)$ solvent. The amount of cholesteryl $\left[{ }^{14} \mathrm{C}\right]$ oleate on TLC was measured with a radioscanner (AMBIS Systems, Inc.).

\section{Assay for Acyl-CoA Synthetase}

Acyl-CoA synthetase (ACS) was assayed by using NEFA C-test kit (Wako Pure Chemical) according to the method described previously [19].

\section{Antimicrobial Activity}

Antimicrobial activity against 14 species of microorganisms was measured by a paper disk method. Media for growth of microorganisms were as follows: GAM agar (Nissui Seiyaku Co.) for Bacteroides fragilis; Waksman agar for Mycobacterium smegmatis; Bacto PPLO agar (Difco) supplemented with $15 \%$ horse serum, $0.1 \%$ glucose, $0.2 \%$ phenol red $(5 \mathrm{mg} / \mathrm{ml})$ and $1.5 \%$ agar for Acholeplasma laidlawii; nutrient agar for Bacillus subtilis, Staphylococcus aureus, Micrococcus luteus, Escherichia coli, Pseudomonas aeruginosa and Xanthomonas oryzae; a medium composed of $1.0 \%$ glucose, $0.5 \%$ yeast extract and $0.8 \%$ agar for Pyricularia oryzae, Aspergillus niger, Mucor racemosus, Candida albicans and Saccharomyces cerevisiae. A paper disk (i.d. $6 \mathrm{~mm}$, Advantic) containing $10 \mu \mathrm{g}$ of a sample was placed on the agar plate. Bacteria except Xanthomonas oryzae were incubated at $37^{\circ} \mathrm{C}$ for 24 hours. Yeasts and $X$. oryzae were incubated at $27^{\circ} \mathrm{C}$ for 24 hours. Fungi were incubated at $27^{\circ} \mathrm{C}$ for 48 hours. Antimicrobial activity was expressed as diameter $(\mathrm{mm})$ of inhibitory zone.

\section{Results}

\section{Fermentation}

A stock culture of strain FKA-25 was inoculated into a 500-ml Erlenmeyer flask containing $100 \mathrm{ml}$ of the seed medium and incubated on a rotary shaker at $27^{\circ} \mathrm{C}$ for 4 days. The main culture was initiated by transferring $200 \mathrm{ml}$ of the seed culture into a 30-liter jar fermenter containing 20 liters of the production medium, and the fermentation was carried out at $27^{\circ} \mathrm{C}$ with agitation at $250 \mathrm{rpm}$. A typical time course of the production is shown in Fig. 2. The concentration of sespendole reached a maximal level $(23 \mu \mathrm{g} / \mathrm{ml})$ on day 4 after inoculation.

\section{Isolation}

The isolation procedure for sespendole is summarized in Fig. 3. The 4-day old culture broth (20 liters) was treated with acetone (20 liters) for 30 minutes and the mixture was 


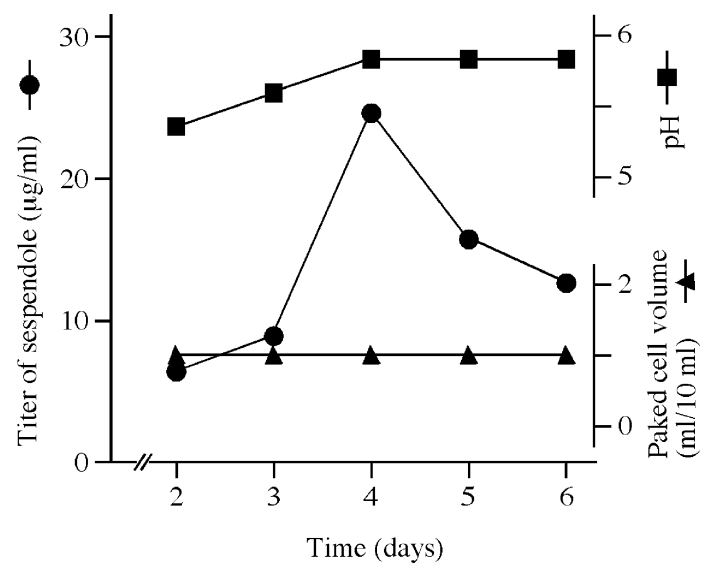

Fig. 2 A typical time course of sespendole production by Pseudobotrytis terrestris FKA-25.

centrifuged to obtain the supernatant. After concentration by removing acetone, the aqueous solution was extracted with ethyl acetate (20 liters). The organic layer was dried over $\mathrm{Na}_{2} \mathrm{SO}_{4}$ and concentrated under reduced pressure to give a brown oil $(4.6 \mathrm{~g})$. The oil dissolved in a small amount of chloroform was applied on a silica gel column (i.d. $2.5 \times 16 \mathrm{~cm}$, Silica gel $60,70 \sim 230 \mu \mathrm{m}$, Merck) previously equilibrated with chloroform, and materials were eluted stepwise with chloroform - methanol solutions (1 liter each, 100:0, 50:1, 9:1, 5:1,1:1 and $0: 100$ ). Sespendole was recovered from the fractions of chloroform methanol $(9: 1)$, which were concentrated under reduced pressure to give a brown powder $(759 \mathrm{mg})$. The powder was dissolved in chloroform and subjected to a second silica gel column chromatography (i.d. $2.0 \times 20 \mathrm{~cm}$, Silica gel 60 , $230 \sim 400 \mu \mathrm{m}$, Merck), and materials were eluted stepwise with chloroform - methanol solutions $(200 \mathrm{ml}$ each, $100: 0$, $100: 1,50: 1,10: 1,5: 1$ and $0: 100)$. The fractions (chloroform-methanol, 10:1) containing sespendole were concentrated to give a yellow powder $(131.5 \mathrm{mg})$. Sespendole was finally purified by HPLC under the following conditions: column, Pegasil ODS (Sensyu Scientific Co., Ltd., i.d. $20 \times 250 \mathrm{~mm}$ ); mobile phase, $60 \%$ aq $\mathrm{CH}_{3} \mathrm{CN}$; flow rate, $8 \mathrm{ml} /$ minute; detection, UV $240 \mathrm{~nm}$. Sespendole was eluted as a peak with a retention time of 16 minutes. The peak was collected and the fraction was concentrated to dryness to give pure sespendole $(13.9 \mathrm{mg})$ as a colorless amorphous solid.

\section{Biological Properties}

Effect of Sespendole on $\left[{ }^{14} \mathrm{C}\right]$ Neutral Lipid Synthesis from $\left[{ }^{14} \mathrm{C}\right]$ Oleic Acid in Macrophages

From the morphological assay, sespendole was found to inhibit the number and size of cytosolic lipid droplets

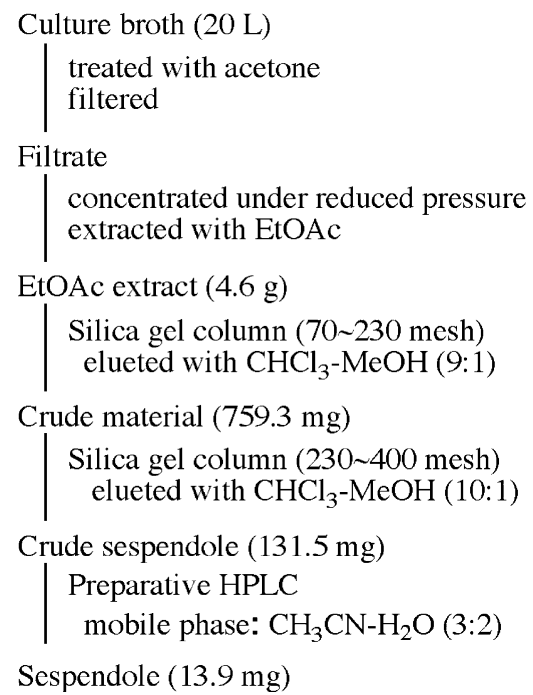

Fig. 3 Purification procedure of sespendole from the culture broth of Pseudobotrytis terrestris FKA-25.

observed in mouse macrophages (Fig. 4). Therefore, the biochemical assay was done to confirm the finding. When macrophages were incubated with the liposomes in the presence of $\left[{ }^{14} \mathrm{C}\right]$ oleic acid, the $\left[{ }^{14} \mathrm{C}\right]$ fatty acid was incorporated into the neutral lipid of $\left[{ }^{14} \mathrm{C}\right] \mathrm{CE}$ and $\left[{ }^{14} \mathrm{C}\right] \mathrm{TG}$ fractions (over $40 \%$ of $\left[{ }^{14} \mathrm{C}\right]$ oleic acid added), main constituents of the lipid droplets. As shown in Fig. 5, sespendole inhibited $\left[{ }^{14} \mathrm{C}\right] \mathrm{CE}$ and $\left[{ }^{14} \mathrm{C}\right] \mathrm{TG}$ syntheses in a dose-dependent fashion with $\mathrm{IC}_{50}$ values of 4.0 and $3.2 \mu \mathrm{M}$, respectively, while the compound showed no effect on $\left[{ }^{14} \mathrm{C}\right]$ phospholipids (PL, mainly phosphatidylcholine) synthesis and viability of macrophages at $20 \mu \mathrm{M}$. On the other hand, structurally related terpendole C (Fig. 1), discovered as an ACAT inhibitor [11], inhibited $\left[{ }^{14} \mathrm{C}\right] \mathrm{CE}$ synthesis specifically $\left(\mathrm{IC}_{50} ; 3.0 \mu \mathrm{M}\right)$, and enhanced $\left[{ }^{14} \mathrm{C}\right] \mathrm{TG}$ and $\left[{ }^{14} \mathrm{C}\right] \mathrm{PL}$ syntheses at $20 \mu \mathrm{M}$ (Fig. 5).

Effect of Sespendole on ACS and ACAT Activities

Since the compound inhibited the both $\left[{ }^{14} \mathrm{C}\right] \mathrm{CE}$ and $\left[{ }^{14} \mathrm{C}\right] \mathrm{TG}$ syntheses in macrophages, ACS was suggested as a possible target of inhibition by sespendole. However, sespendole showed no ACS inhibition at $150 \mu \mathrm{M}$. Furthermore, the compound showed almost no effect on ACAT $\left(\mathrm{IC}_{50} ; 550 \mu \mathrm{M}\right)$ either.

Antimicrobial Activity

Sespendole showed weak antimicrobial activity against $B$. subtilis (inhibition zone, $7.0 \mathrm{~mm}$,) and $M$. smegmatis $(9.5 \mathrm{~mm})$ at $10 \mu \mathrm{g} / 6 \mathrm{~mm}$ disk among the 14 microorganisms tested. 


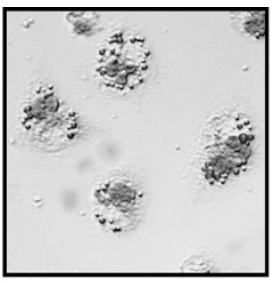

Sespendole
$0 \mu \mathrm{M}$ (Control)

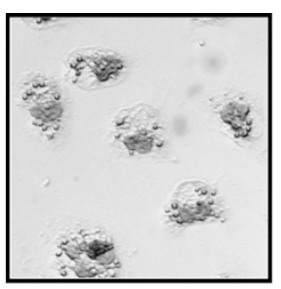

$2.0 \mu \mathrm{M}$

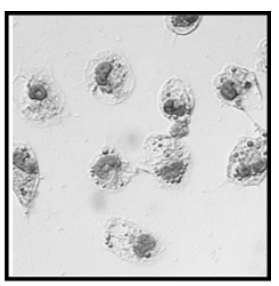

$20 \mu \mathrm{M}$

Fig. 4 Effects of sespendole on lipid droplet accumulation in macrophage.
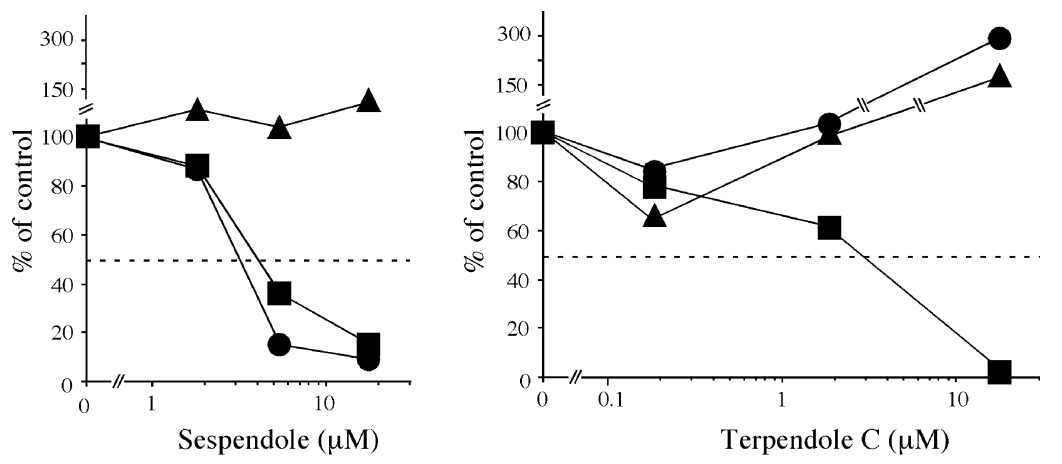

Fig. 5 Effects of sespendole and terpendole $\mathrm{C}$ on $\left[{ }^{14} \mathrm{C}\right] \mathrm{CE},\left[{ }^{14} \mathrm{C}\right] \mathrm{TG}$ and $\left[{ }^{14} \mathrm{C}\right] \mathrm{PL}$ syntheses in macrophages.

TG (•), CE (ם) and PL ( $\mathbf{\Delta})$.

\section{Discussion}

A number of indoloditerpene compounds have been reported as fungal metabolites [20]. However, sespendole is the first fungal metabolite having an indolosesquiterpene skeleton to our knowledge. The structure elucidation will be reported in the near future. We previously discovered terpendoles, members of indoloditerpenes, as inhibitors of ACAT. Therefore, the inhibitory effect on lipid droplet formation in macrophages was compared between sespendole and terpendole C (Fig. 5). Terpendole C specifically inhibited CE synthesis in macrophages due to its ACAT inhibition, while sespendole inhibited both CE and TG syntheses, suggesting that the inhibition site of sespendole is different from that of terpendole C. In fact, sespendole showed almost no effect on ACAT. Furthermore, the compound showed no effect on ACS, either, though predicted from the finding that it inhibited both neutral lipids to similar extents like triacsins [21]. The target molecule of sespendole in lipid droplet formation by macrophages remains to be defined.

Acknowledgements This work was supported by the grants of
Scientific Research on Priority Areas 16073215 and of the 21st Century COE Program from the Ministry of Education, Culture, Sports, Science and Technology, Japan and of Hoh-ansha Foundation, Japan.

\section{References}

1. Uchida R, Imasato R, Shiomi K, Tomoda H, Ōmura S. Yaequinolones $\mathrm{J} 1$ and $\mathrm{J} 2$, novel insecticidal antibiotics from Penicillium sp. FKI-2140. Org Lett 7: 5701-5704 (2005)

2. Uchida R, Imasato R, Yamaguchi Y, Masuma R, Shiomi $\mathrm{K}$, Tomoda H, Ōmura S. New insecticidal antibiotics, hydroxyfungerins $\mathrm{A}$ and $\mathrm{B}$, produced by Metarhizium sp. FKI-1079. J Antibiot 58: 804-809 (2005)

3. Uchida R, Imasato R, Yamaguchi Y, Masuma R, Shiomi $\mathrm{K}$, Tomoda H, Ōmura S. New sesquicillins, insecticidal antibiotics produced Albophoma sp. FKI-1778. J Antibiot 58: 397-404 (2005)

4. Koyama N, Nagahiro T, Yamaguchi Y, Ohshiro T, Masuma R, Tomoda H, Ōmura S. Spylidone, a novel inhibitor of lipid droplet accumulation in mouse macrophages produced by Phoma sp. FKI-1840. J Antibiot 58: 338-345 (2005)

5. Fukuda T, Yamaguchi Y, Masuma R, Tomoda H, Ōmura $\mathrm{S}$. Citridones, new potentiators of antifungal miconazole activity, produced by Penicillium sp. FKI-1938. I. Taxonomy, 
fermentation, isolation and biological properties. J Antibiot 58: 309-314 (2005)

6. Fukuda T, Matsumoto A, Takahashi Y, Tomoda H, Ōmura S. Phenatic acids $\mathrm{A}$ and $\mathrm{B}$, new potentiators of antifungal miconazole activity produced by Streptomyces sp. K030132. J Antibiot 58: 252-259 (2005)

7. Arai M, Koizumi Y, Sato H, Kawabe T, Suganuma M, Kobayashi H, Tomoda H, Ōmura S. Boromycin abrogates bleomycin-induced G2 checkpoint. J Antibiot 57: 662-668 (2004)

8. Matsuda D, Namatame I, Tomoda H, Kobayashi S, Zocher R, Kleinkauf H, Ōmura S. New beauveriolides produced by amino acid-supplemented fermentation of Beauveria sp. FO-6979. J Antibiot 57: 1-9 (2004)

9. Tomoda H, Ōmura S. Screening for inhibitors of lipid metabolism. In Enzyme Technologies for Pharmaceutical and Biotechnological Applications. Ed., Kirst HA., pp. 343-378, Marcel Dekker, Inc., New York, Basel (2001)

10. Domsch KH, Gams W, Anderson TH. Pseudobotrytis. In Compendium of Soil Fungi. Vol. 1, pp. 674-675, Verlag (1993)

11. Yamaguchi Y, Masuma R, Kim YP, Uchida R, Tomoda H, Ōmura S. Taxonomy and secondary metabolites of Pseudobotrytis sp. FKA-25. Mycoscience 45: 9-16 (2004)

12. Huang XH, Tomoda H, Nishida H, Masuma R, Ōmura S. Terpendoles, novel ACAT inhibitors produced by Albophoma yamanashiensis. I. Production, isolation and biological properties. J Antibiot 48: 1-4 (1995)

13. Huang XH, Tomoda H, Nishida H, Masuma R, Ōmura S. Terpendoles, novel ACAT inhibitors produced by Albophoma yamanashiensis. II. Structure elucidation of terpendoles A, B, C and D. J Antibiot 48: 5-10 (1995)

14. Tomoda H, Tabata N, Yang DJ, Takayanagi H, Ōmura S. Terpendoles, novel ACAT inhibitors produced by Albophoma yamanashiensis. III. Production, isolation and structure elucidation of new components. J Antibiot 48: 793-804 (1995)

15. Kobayashi, T, Masuma R, Ōmura S, Watanabe K. Materials for the fungus flora of Japan (47). Mycoscience 35: 399-401 (1994)

16. Namatame I, Tomoda $\mathrm{H}$, Arai $\mathrm{H}$, Inoue $\mathrm{K}$, Ōmura $\mathrm{S}$. Complete inhibition of mouse macrophage-derived foam cell formation by triacsin C. J Biochem 125: 319-327 (1999)

17. Bligh EG, Dyer W. A rapid method of total lipid extraction and purification. Can J Biochem Physiol 37: 911-917 (1959)

18. Uelmen PJ, Oka K, Sullivan M, Chang CCY, Chang TY, Chang L. Tissue-specific expression and cholesterol regulation of acylcoenzyme A:cholesterol acyltransferase (ACAT) in mice. J Biol Chem 270: 26192-26201 (1995)

19. Ōmura S, Tomoda H, Xu QM, Takahashi Y, Iwai Y. Triacsins, new inhibitors of acyl-CoA synthetase produced by Streptomyces sp. J Antibiot 39: 1211-1218 (1986)

20. Nozawa K. Biologically active indoloditerpenes from Aspergillus and Penicillium. In Proceeding of the 38th Annual Meeting of the Mycological Society of Japan. pp. 10-11 (1994)

21. Namatame I, Tomoda H, Arai H, Inoue K, Ōmura S, Complete inhibition of mouse macrophage-derived foam cell formation by triacsin C. J Biochem 125: 319-327. (1999) 